\title{
Antoni Zając
}

Uniwersytet Warszawski

(iD) http://orcid.org/0000-0002-8430-5455

\section{„I czyje to wszystko?" \\ Fantomy pamięci i transfery traumy w Krótkiej wymianie ognia Zyty Rudzkiej}

\author{
"Whose Is It, Anyway?" \\ The Phantoms of Memory and the Transmission of Trauma \\ in Zyta Rudzka's Krótka wymiana ognia
}

\begin{abstract}
This article aims to provide a preliminary interpretation of Zyta Rudzka's novel entitled Krótka wymiana ognia (A Short Exchange of Fire). It is analysed through the lens of interdisciplinary Memory and Trauma Studies as well as Maria Török and Nicolas Abraham's psychoanalytical thought - special attention is paid to the concept of transgenerational transmission of trauma. The author presents three main series of events (which occur not only in reality but also in the phantasmatic order) which affect the complicated relationship between women from three generations of the same family. Shreds of memory that circulate between them gradually lose an unambiguous affiliation and become a part of a somatic and sensual traumatic palimpsest.
\end{abstract}

Key words: Phantom, postmemory, post-traumatic subject, transgenerational trauma, Zyta Rudzka

Streszczenie: Artykuł stanowi próbę interpretacji powieści Zyty Rudzkiej zatytułowanej Krótka wymiana ognia. Dochodzi w nim do odczytania tego utworu za pomocą kategorii zaczerpniętych z myśli psychoanalitycznej Marii Török i Nicolasa Abrahama oraz z interdyscyplinarnych studiów nad pamięcią i traumą ze szczególnym uwzględnieniem zagadnienia transgeneracyjnego przekazu traumy. Autor przedstawia trzy podstawowe łańcuchy rzeczywistych i obecnych w porządku fantazmatycznym zdarzeń, które wpływają na skom- 
plikowaną relację pomiędzy kobietami należącymi do trzech pokoleń tej samej rodziny. Krążący między nimi pamięciowy przekaz jest zaburzony i stopniowo wytraca jednoznaczną afiliację, stając się traumatycznym palimpsestem o charakterze sensualnym i somatycznym.

Słowa kluczowe: Fantom, podmiot posttraumatyczny, postpamięć, transgeneracyjny przekaz traumy, Zyta Rudzka

Krótka wymiana ognia to siódma powieść Zyty Rudzkiej. Wydana w 2018 roku książka jest efektem powrotu autorki do twórczości prozatorskiej po kilkuletnim okresie pracy nad formami dramatycznymi, m.in. nagradzanymi sztukami Cukier Stanik i Zimny bufet oraz - co nie bez znaczenia - utworem zatytułowanym Krótka wymiana ognia ${ }^{1}$. Wypada uznać go za tekst autonomiczny (jest zasadniczo odmienny od powieści pod względem formalnym, językowym, częściowo również tematycznym), jednak już tam pojawiły się pewne postaci i wątki, a nawet sformułowania², które zostały później poddane nowemu opracowaniu ${ }^{3}$, a następnie złożone $\mathrm{w}$ narracyjną formę, fragmentaryczną i wewnętrznie popękaną ${ }^{4}$.

${ }^{1}$ Z. RudzKa: Krótka wymiana ognia. [Utwór dramaturgiczny]. „Dialog” 2014, nr 4, s. 21-41.

${ }^{2}$ W dramacie Rudzkiej naśladowana jest struktura trenu, a nawiązania do różnych tekstów kultury (tzw. wysokiej i tzw. popularnej) w zestawieniu z tematyką tekstu mogą wywołać skojarzenia z Utworem o Matce i Ojczyźnie Bożeny Keff. Te elementy w powieści nie występują, obecne są za to niektóre postaci, takie jak Zuzanna i Werner, a także wątek samobójstwa kobiet uciekających przed żołnierzami Armii Czerwonej. Powracają sceny (kobiety topiące się w jeziorze, obcinanie warkocza) i całe frazy (np. „Jacy są teraz mężczyźni? / Mają delikatne dłonie. Wrażliwe. Jak małe kraby”, „Tam jest taki widok. Eine atemberaubende". Ibidem, odpowiednio s. 21 i 22 oraz Z. RudzkA: Krótka wymiana ognia. Warszawa 2018, odpowiednio s. 20 oraz s. 169 - dalsze odniesienia do cytatów z powieści Rudzkiej oznaczam skrótem Kwo oraz podaję numer strony).

${ }^{3}$ Można to postępowanie powiązać z metodą twórczą, o której Rudzka mówi w wywiadzie z Agnieszką Sowińską: „Ja właściwie piszę, przepisując. Krótka wymiane ognia przepisywałam cały czas - tak, by uzyskać krótkie zdania, a krótkie zdania długo się pisze. Nie tyle odejmowałam słowa, co w nich grzebałam, zawsze szukając tego jedynego". A. Sowiśska: Czas na inne piosenki. Rozmowa z Zyta Rudzka. „Dwutygodnik” 2018, nr 3. https://www.dwutygodnik. com/artykul/7740-czas-na-inne-piosenki.html [dostęp: 1.05.2020].

${ }^{4}$ Wśród licznych klasyfikacji gatunkowych lub narratologicznych, które pozwoliłyby opisać strukturę powieści Rudzkiej, chciałbym zwrócić uwagę na 
Powieść spotkała się z dużym zainteresowaniem krytyków i krytyczek - to dotychczas najszerzej komentowany utwór Rudzkiej. Recepcja Krótkiej wymiany ognia była na ogół pozytywna - w 2019 roku książka otrzymała Nagrodę Literacką Gdynia, uzyskała również nominację m.in. do Nagrody Literackiej „Nike”. Dariusz Nowacki uznał, że zaletą powieści jest brak jasnych rozwiązań fabularnych i wyrazistych rozstrzygnięć moralnych ${ }^{5}$, a na znaczenie niedomówień czy sekretów w planie narracyjnym powieści zwracała uwagę Martyna Okrajni ${ }^{6}$. Eksperymentalność prozy Rudzkiej, która odzwierciedla skomplikowaną strukturę kruchej pamięci, stała się dla Olgi Wróbel podstawą do wyróżnienia Krótkiej wymiany ognia spośród analizowanych przez nią powieści napisanych przez kobiety i wydanych w 2018 roku: "Z tarczą zostaje tylko Zyta Rudzka z lubieżnymi, starymi bohaterkami, mielącymi w ustach frazy, które nie przynoszą ulgi"7. Za "Minimalistyczną sagę o trzech pokoleniach kobiet" $^{\prime \prime}$, podatną na psychoanalityczne interpretacje uznała książkę z kolei Kinga Dunin, która stwierdziła, że Rudzka napisała „chyba najciekawszą powieść w polskiej literaturze, jaką [Dunin - A.Z.] czytała od lat"

Inny ton przybrała recenzja Krótkiej wymiany ognia autorstwa Marcina Bełzy. Ma ona charakter polemiczny względem dotychczasowej recepcji książki - to, co we wcześniejszych komentarzach zostało poczytane za walor, u Bełzy jest rozpatrywane negatywnie, a „kanonizacja tej powieści"10 jest dlań niezrozumiała i nieuzasadniona. W tekście pisanym demaskatorskim tonem autor uznaje, że Krótka wymiana ognia nie jest w stanie sprostać etycznym wymogom stawianym narracji dotyczącej zdarzeń granicznych, ekstremalnych,

możliwość określenia jej mianem „powieści kubistycznej”. Tak późne utwory Leopolda Buczkowskiego nazywa Piotr SADzIK - zob. Idem: Rozpylenia. Marańskie montaże Leopolda Buczkowskiego. „Teksty Drugie” 2019, nr 4, s. 107.

${ }^{5}$ D. Nowaскі: "Krótka wymiana ognia” Zyty Rudzkiej: świetny powieściowy powrót po kilkunastu latach przerwy. "Gazeta Wyborcza”, 9.04.2018.

${ }^{6}$ M. Окrajni: Zakotwiczenie (w) przeszłości (Zyta Rudzka: "Krótka wymiana ognia"). „artPapier" 2018, nr 13. http://artpapier.com/index.php?page=artykul\&wyd anie $=351 \&$ artykul=6865\&kat=1 [dostęp: 1.05 .2020 ].

7 O. WróBel: Odważniej. „Dwutygodnik” 2018, nr 3. https://www.dwutygod nik.com/artykul/7696-odwazniej.html [dostęp: 1.05.2020].

${ }^{8}$ K. Dunin: Zajrzeć do studni. https://krytykapolityczna.pl/kultura/czytaj-dalej/ kinga-dunin-czyta/zyta0rudzka-recenzja-zajrzec-do-studni/ [dostęp: 1.05.2020].

${ }^{9}$ Ibidem.

${ }^{10}$ M. BeŁza: Zimne ognie. „Mały Format” 2018, nr 4. http://malyformat.com/ 2018/04/zimne-ognie/ [dostęp: 1.05.2020]. 
skutkujących traumą lub aktywujących wypartą przeszłość. Zdaniem Bełzy utwory, w których taka tematyka jest podejmowana, muszą ukazywać kryzys nie tylko doświadczenia, lecz także medium służącego do jego reprezentacji, jednakże $\mathrm{w}$ ostatecznym rozrachunku powinny reprezentować pewien typ decorum, ustanawiającego odpowiedni balans między etyczną zawartością tekstu a jego stroną estetyczną. Język ma nade wszystko służyć opowiadaniu i dawać świadectwo możliwości zaistnienia koherentnej wypowiedzi - jeżeli bowiem eksploracje stylistyczne przysłonią sensy przekazywane przez tekst (sensem naczelnym powinno być przezwyciężenie niewypowiadalności), proza nabierze cech autokarykatury i nie będzie można jej zawierzyć.

Dla Bełzy co najmniej niepokojący musi być więc szereg elementów obecnych w Krótkiej wymianie ognia - specyficznie „rwana” narracja, wykorzystanie językowych klisz, mieszanie stylistycznych rejestrów czy sceny, w których to, co najtragiczniejsze, jest jednocześnie $\mathrm{w}$ dziwny sposób przesycone humorem. Autor postrzega tę strategię twórczą jako koniunkturalną, zaś w kluczowym akapicie recenzji stwierdza:

Zarzucam tej powieści grzech najcięższy: obracanie Traum i Historii w przedmiot gry, oswajanie przez estetyzowanie - $\mathrm{i}$ to właśnie teraz, kiedy potrzeba nam raczej postawienia $\mathrm{w}$ stan niepokoju i najwyższej moralnej niewygody. Wpisuje się ona w groźną tendencję literacką, która opiera się na żonglowaniu wielkimi tematami, z czego na ogół niewiele wynika - lub wychyla się porażająca i znieczulająca banalizacja ${ }^{11}$.

Więcej niż symptomatyczny jest fakt, że Bełza postanowił oba najważniejsze tu pojęcia napisać wielką literą - tym samym wskazuje jedyny właściwy tryb opisu stanów wyjątkowych rzeczywistości: jest nim wzniosła, sakralizująca doświadczenie narracja tragiczna. Wydaje się zaś, że przekonanie całkowicie odmienne stanowi źródło twórczości Rudzkiej - autorki usilnie odmawiającej pisania o traumie przez wielkie "T" i przekonanej o konieczności eksperymentalnej pracy z językowym naddatkiem, który Bełza pragnie wykluczyć z tego typu literatury. Krótka wymiana ognia to faktycznie rewers narracji traumatycznej tworzonej według literaturoznawczo uprawomocnionych dyskursywnych zasad - w powieści jej próbka

${ }^{11}$ Ibidem. 
zostaje zresztą przywołana w trybie ironicznym, w scenie wieczoru autorskiego, podczas którego główna bohaterka, poetka Roma Dąbrowska, wysłuchuje prelekcji o własnej twórczości, zupełnie nie odnajdując się w swojej charakterystyce:

Podglądaczka istnienia. Doskonała w anatomii przedmiotów. Sekcji rzeczy. Odgrzebywaniu istnień. Dmucha w popiół. Wychwytuje fragment. Ukryty zarys. Nieważny detal. Schowany szczegół. Nieśmiały ślad. Zatartą poszlakę. Zapomniany trop.

Kwo, s. 33

Dość daleko Rudzkiej do cytowanej tu pastiszowo retoryki mającej swoje korzenie w zapiskach Maurice'a Blanchota i Jean-François Lyotarda ${ }^{12}$; jej dokonania należałoby charakteryzować w bliskości wszystkich tych twórców i twórczyń, którzy wychodzą poza „hermeneutykę popiołu” i renegocjują warunki jednostkowego zapisu, dokonującego się w dystansie względem uporządkowanej struktury literackiego świadectwa służebnego ${ }^{13}$. Idiom Rudzkiej jest odmienny od spiżowego, surowego tonu źle rozumianego realizmu traumatycznego ze względu na różnorakie odkształcenia czy suplementacje, zarówno w materii języka, jak i w sposobie porządkowania i prezentowania zdarzeń. Poszatkowane zdania, zapętlenia czy zaburzone rytmy tej prozy mają odzwierciedlać czasoprzestrzenne komplikacje, w jakie uwikłana jest opowieść tego, kto doświadcza traumy, lub próbuje zmagać się z niejasnym, sekretnym przekazem o traumie doświadczonej przez najbliższych. Doświadczenie teraźniejszości niejasno podszytej przez to, co minione, a co nie znajduje dla siebie normatywnego wzorca wypowiedzenia, dobrze charakteryzuje użyte przez Rudzką w Zimnym bufecie sformułowanie „czas teraźniejszy złożony"14: w nim właśnie, jak się wydaje, umiejscowione są bohaterki Krótkiej wymiany ognia, a zatem kobiety należące do trzech pokoleń tej samej rodziny, których historie wielokrotnie rozplatają i splatają się. Matrylinearny przekaz jest zagmatwany, zaś substancjalne dla niego traumy obciążaja, choć nie zostają wypowiedziane, przywołane po imieniu.

12 Por. J. Leociak: Doświadczenie graniczne. Studia o dwudziestowiecznej formie reprezentacji. Warszawa 2009.

${ }^{13}$ Do takich twórców zaliczałbym m.in. Leo Lipskiego, Leopolda Buczkowskiego i Piotra Rawicza.

${ }^{14}$ Z. Rudzka: Zimny bufet. http://www.gnd.art.pl/wp-content/uploads/2014/05/ zimny_bufet_zyta_rudzka.pdf [dostęp: 1.05.2020]. 
W utworze Rudzkiej słowa, wspomnienia, pamięciowe artefakty nieustannie migrują między przywoływaną już Romą Dąbrowską, jej bezimienną „mamulką”, która przeżyła wejście Armii Czerwonej na tereny Śląska, oraz córką Zuzanną, wybitną pianistką, która postanawia niespodziewanie zerwać kontakty z rodzicami. Te strzępy doświadczenia nie mogą podlegać inwentaryzacji czy mnemotechnicznym zabiegom, a listy obiektów obciążonych traumatycznym znaczeniem nie zamykają się. Enumerowane przedmioty są obecne w myśleniu Romy, mimo że ta nie rozumie ich znaczenia, ponieważ, jak w porządku narracji dowiadujemy się znacznie później, są one częścią nigdy niewypowiedzianego doświadczenia jej matki: „Wciąż widzę bucior, rączki lalek, kondom, osmalone deski, lód, omszałą cembrowinę, przerębel; to jest wszędzie" (Kwo, s. 10). Zadawane w powieści ważne pytanie „I czyje to wszystko?” (Kwo, s. 66) wskazuje na fakt, że w rodzinnym obiegu krąży nie tyle spójna opowieść o przeszłości, ile raczej jej fragmenty pozbawione jasnej afiliacji, sekretne przekazy, których obecność wyczuwana jest jedynie podskórnie.

Ten model wielokierunkowych transferów traumy jest zgodny z rozwijaną przez psychoanalityka Nicolasa Abrahama koncepcją fantomu. Według Abrahama to, co nas nawiedza i nęka, nie musi być koniecznie traumą przeżytą przez nas samych. Może być to również przekaz odziedziczony, chociażby przechodzący z pokolenia na pokolenie. Co ważne, nie chodzi tu o wypowiedzianą w jasny i spójny sposób prawdę o traumatycznym zdarzeniu, ale raczej o wszystkie przemilczenia i sekrety, które w postaci zagadkowych, zaszyfrowanych symptomów ujawniają się w dużym rozproszeniu. Przekaz, jednocześnie tak silnie na nas wpływający i tak niejasny, opiera się zadawanym mu pytaniom. Nadchodzi on już jako zniekształcony, już w rozbitych słowach. Trauma bowiem skrywa się w załomach języka. Co więcej, traumatyczna opowieść rodzinna podlega mechanizmowi retroaktywnych naznaczeń i efektowi Nachträglichkeit. Na kształt tej opowieści modyfikująco wpływają więc narracje kolejnych członków rodziny zmuszonych do konfrontacji z przeszłością własną i niewłasną.

Pamięć działa tu organicznie i hybrydycznie zarazem - żywe współdzieli przestrzeń z martwym, a przynależne tym porządkom elementy w niepożądany i nieoczekiwany sposób zrastają się ze sobą, protezując się wzajemnie swoimi ubytkami. Abraham pisze:

Fantom jest tworem nieświadomości, która - nie bez powodu nigdy się nie uświadomiła. [...] Jest oczywiste, że funkcją fanto- 
mu nie jest dynamiczne wyparcie. Jego kompulsywne, okresowe powroty nie mogą być ujęte przez definicję tworzenia się objawu w wyniku ujawnienia wypartej treści; działa on jak brzuchomówca, obcy twór w topografii mentalnej pacjenta. Wyobrażenia powstałe w wyniku obecności tego obcego nie mają nic wspólnego z klasycznymi fantazjami. Nie utrzymują topograficznego status $q u o$ ani nie odzwierciedlają jego zmiany. Zamiast tego, w swojej niechcianej obecności przybierają formę surrealistycznych fantasmagorii lub wypowiedzi przypominających twórczość OuLiPo ${ }^{15}$.

Podmiot, który pragnie w jakiś sposób wypowiedzieć te zagmatwane przekazy, nie ma do dyspozycji mowy, którą mógłby swobodnie władać. Nie jest mu dostępna jakakolwiek esencjonalna narracja dotycząca punktowej traumy. Trauma bowiem zaplata się z siecią wydarzeń i fantazmatów, spośród których część nadchodzi jako niejawny przekaz od strony innego. "Ja" posługuje się ze zmiennym szczęściem owym swoim-nieswoim językiem, tak charakteryzowanym przez Rudzką:

Słowa to sukienki matki. Kuse, dziecięce, spod szafy wyszarpane. Po starszej siostrze. [...] Albo takie stroje, co piją, wrzynają się, cisną, zostawiają ślady, ale nie da się tych szmat wyrzucić, oddać, zawsze przychodzi na nie czas, same się przez głowę cisną.

Kwo, s. 17

Jednocześnie jednak tylko w języku - w jego kryzysach i ekscesach - mogą ujawnić się „krótkie wymiany ognia”, czyli intensywne transfery doświadczeń, niezwykłe rezonanse różnic i powtórzeń czy wreszcie postpamięciowe ${ }^{16}$ ujawnienia polegające, jak pisze Aleksandra Ubertowska, na „wywołaniu [...] mglistych zarysów postaci i rzeczy" oraz "migotliwych fantomów, które w istocie pogłębiają świadomość braku"17.

Nawiedzona przez widma wielu cudzych przeszłości Roma zmaga się jednak również z tym, co namacalnie doczesne - szcze-

15 N. Abraham: Notes on Phantom: A Complement to Freud's Metapsychology. Trans. N. RAND. „Critical Inquiry” 1987, vol. 13, no 2, s. 287-292. Na potrzeby niniejszego artykułu fragment anglojęzycznej wersji tekstu przełożył Jakub Żabiński-Sikorski.

${ }^{16}$ Zob. M. Hirsch: Żałoba i postpamięć. Przeł. K. Bojarska. W: Teoria wiedzy o przeszłości na tle współczesnej humanistyki. Red. E. Domańska. Poznań 2010, s. 247-280.

17 A. Uвеrтоwsкa: Praktykowanie postpamięci. Marianne Hirsch i fotograficzne widma z Czernowitz. „Teksty Drugie” 2013, nr 4, s. 283. 
gólnie w początkowych partiach powieści bohaterka czuje bowiem, że wraz z wiekiem jej ciało traci witalność, niszczeje i rozkłada się: „Pokancerowana. W plamach. Liszajach. Wyżłobieniach. Koroduję. Kwilę w strupkach szarych. Sflaczała i obrzmiała. Spocona, obśliniona od myśli" (Kwo, s. 38). Roma odczuwa swoje ciało jako zdefragmentowane i coraz trudniej jest jej się w nim odnaleźć: „Od lat każdy gest oddziela mnie od siebie, znikam gwałtowniej niż linie papilarne na gorącym fajansie filiżanki" (Kwo, s. 30).

Ciało to podlega opisywanemu przez Catherine Malabou procesowi destrukcyjnego, plastycznego starzenia się ${ }^{18}$. Wbrew koncepcji francuskiej filozofki nie wytraca ono jednak pamięci dotyku - tego, co $\mathrm{w}$ nim bolesne, ale również tego, co powiązane $\mathrm{z}$ niespełnionymi i spełnionymi pragnieniami. To ważna cecha pisarstwa Rudzkiej seksualność, jednostkowe doświadczenie traumatyczne i cząstkowa partycypacja w pamięci zbiorowej nie są tu rozłącznymi dziedzinami życia, ale mieszają się często w sposób, który w omawianej wcześniej optyce może wydać się bluźnierczy lub niesmaczny ${ }^{19}$.

Wiele miejsca Rudzka poświęca mężczyznom ważnym w życiu Romy - mężczyznom, którzy „są zawsze umorusani sobą. Nawet już dawno martwi żyją w ciągłym ruchu" (Kwo, s. 64), tak jakby byli obecni zawsze w widmowym powtórzeniu. Tak jest chociażby w przypadku nieudanego związku z Piotrem, który kończy się wraz z dokonaniem aborcji przez Romę (spędzony płód wydaje się pierwszym z serii „utraconych dzieci” nękających i nawiedzających bohaterkę: „Miłość do tego dziecka będzie powracać [...] jak echo po niespisanych trenach"; Kwo, s. 59) - później zaś Piotr pojawia się powtórnie $\mathrm{w}$ fantazmatycznym odkształceniu, dziwnie zresztą przypominając tytułową postać Piotrusia Leo Lipskiego: „Ktoś mi powiedział, że Piotruś zachorował. Jeszcze przed wylotem. Coś się stało $\mathrm{z}$ jego nogą. Z dnia na dzień stała się jak mątwa. Wyblakła, rozmiękła w konturach" (Kwo, s. 63) ${ }^{20}$.

Dużo większą rolę w planie powieści odgrywa z kolei wątek romansu Romy z lekarzem Arnoldem Rosnerem - człowiekiem, który

${ }_{18}$ C. Malabou: Ontologia przypadłości. Esej o plastyczności destrukcyjnej. Przeł. P. SKALSKI. Warszawa 2017.

${ }^{19}$ Oprócz tekstu Bełzy zob. również kuriozalną recenzję: B. KLImowicz: Straszna pani bez godności, czyli przemilczenia w recepcji „Krótkiej wymiany ognia” Zyty Rudzkiej. „Kultura Liberalna” 2018, nr 22. https://kulturaliberalna. pl/2018/05/29/beata-klimowicz-recenzja-zyta-rudzka-krotka-wymiana-ognia/ [dostęp: 1.05.2020].

${ }^{20}$ Kolejną postacią w tej linii jest inny Piotr, bohater Zdroju Barbary Klickiej - to także postać o skomplikowanej somatyczności. Zob. B. KLIcKA: Zdrój. Warszawa 2019, s. 71-108. 
nie może uwolnić się od ciążącej na nim śmierci matki $\mathrm{w}$ obozie koncentracyjnym („Myślisz, że ten syk [chodzi o syk gazu - A.Z.] się z pępowiną odcina?"; Kwo, s. 95), a który zostaje wraz z wydarzeniami marca 1968 roku zmuszony do wyjazdu z Polski. Traumatyczna kontaminacja, w której Marzec retroaktywnie łączy się z Zagłada, to motyw obecny zarówno w poprzednich utworach Rudzkiej (w Mykwie i Fastrydze), jak i w innych polskich tekstach literackich, na co zwraca uwagę Anna Artwińska ${ }^{21}$. W Krótkiej wymianie ognia wątek ten opracowany jest jednak $\mathrm{w}$ sposób interesujący $\mathrm{w}$ szczególności ze względu na postać żony Rosnera, Liliany, która, gdy tylko dowiaduje się o konieczności opuszczenia kraju, postanawia zaadoptować przebywającą $\mathrm{w}$ sierocińcu, uzdolnioną muzycznie dziewczynkę. Z kolejnych fragmentów dowiadujemy się, że córka Rosnerów, opuszczona przez „nową" matkę, wyjeżdża wraz z ojcem do Tel Awiwu i tam wraz z nim mieszka. Co jednak dziwne, Roma podejmuje w późniejszej sekwencji tekstu opowieść Liliany i przemawia za nią (by powrócić do metafory Nicolasa Abrahama) niczym brzuchomówczyni: „A ja mam córkę. Mieszka w Tel Awiwie. U ojca. Uciekła tam" (Kwo, s. 140).

Fantomatyczny przekaz rymuje się z faktycznym porządkiem wydarzeń - mam tu na myśli przede wszystkim ucieczkę córki Romy, utalentowanej muzycznie Zuzanny, z rodzinnego domu. Młoda pianistka, która w wieku osiemnastu lat opuszcza swoją rodzinę na zawsze, to postać właściwie niema i dość tajemnicza. Ukazana jest jako bliźniacza replikacja matki: „Wyglądałyśmy jak matrioszki od jednego kompletu. Ja większa, ona mniejsza. Rozmnożenie postaci zyskiwało na sile, kiedy widziało się nas razem" (Kwo, s. 11)22.

Zuzanna decyduje się wykonać gest zerwania i próbuje wyznaczyć własny porządek, który nie musiałby obejmować zmagań z podziurawioną rodzinną pamięcią - tego $\mathrm{w}$ stosunku do swojej matki nie była w stanie dokonać Roma. Zuzanna pojawia się zresztą przede wszystkim jako jej projekcja. Trudno bowiem zakładać, że historia światowej kariery pianistycznej dziewczynki rozwija się w porządku rzeczywistym, co sugeruje sama Rudzka: „Proszę pamiętać, że to jest pisane $\mathrm{w}$ pierwszej osobie. Więc ja bym do końca nie wierzyła Romie we wszystko, co mówi. Może jej córka miała jakiś koncert w Japonii. Ale czy była tak czczona?"23.

${ }^{21}$ A. Artwińska: „Odrodziły się traumy z czasów Zagłady”. Marzec 1968 jako narracja postkatastroficzna. „Poznańskie Studia Polonistyczne” 2015, nr 25, s. 187-208.

${ }^{22}$ Metafora matrioszki pojawia się również - za sprawą postaci Matriochy, Matriony i Matrioszki - w Zimnym bufecie.

${ }^{23}$ A. SowińsKa: Czas na inne piosenki... 
W życiu rodziców, Romy i Mateusza, Zuzia pojawia się właśnie jako szczególny rodzaj milczenia. Za przekaz od niej Roma uznaje głuche telefony: są „dzieleniem się [z córką - A.Z.] słowami, których nie ma” (Kwo, s. 73) - albo niczym nieuleczalna choroba: „Mamy ataki córki. Tak jak inni mają ataki astmy. Migren. Wyrostka. Idiotycznego śmiechu bez śmiechu" (Kwo, s. 76).

Wyrostek robaczkowy Zuzanny jest tu zresztą ważny - pozostaje jedynym materialnym artefaktem, somatycznym szczątkiem, wokół którego koncentrować się może niezakończona żałoba Romy:

Budzę się i natychmiast przypominam sobie o słoiku. Przynoszę go z przedpokoju i ustawiam na linii wzroku. Kładę się na łóżku i patrzę na ślepą cewkę w formalinie, unosi się jak szczątek embrionu, fragment zwykłego dziecka. Wtedy krótko myślę o Zuzannie. Jest inaczej. Przez chwilę.

Kwo, s. 158

Ucieczka Zuzanny nie kończy się oczekiwaną skuteczną separacja, dziewczyna zostaje bowiem po latach odnaleziona - jak się okazuje, "Zuzanka znalazła schronienie niedaleko mamulki” (Kwo, s. 191) i pod względem fizjonomii przypomina również swoją babkę; jak się okazuje, nie była w stanie sprawić, by jej życie było pozbawione replikacji traum matki i babki. To powtórzenie, ważne szczególnie z punktu widzenia teorii traumy transgeneracyjnej ${ }^{24}$, obecne jest wcześniej w powieści, a pojawia się w jej bardzo ważnym momencie, właściwie uruchamiając najważniejszą linię niejawnego, fantomowego przekazu. Chodzi o skomplikowany wątek „mamulki” Romy, która utraciła swoje imię.

Mamulka, snująca poszatkowaną retrospektywną opowieść, skupiona jest na powtarzaniu imion, które początkowo stanowią jedynie niepewny znacznik bezpowrotnie minionych zdarzeń. Gdy zdarza się to po raz pierwszy, brzmi to następująco:

Ingeborga. Renate. Zuzanka. Nina...

Jaka Zuzanka?!, wtrącam się z wrzaskiem. Jaka Zuzanka?! Jej tam nie było. Ona się jeszcze nie urodziła. Co ty gadasz?! Nawet mnie wtedy nie było.

Ingeborga. Renate. Nina, poprawia się mamulka.

Kwo, s. 19

${ }^{24}$ Zob. ciekawe case study: I. ŁUсKA, P. NowaK: Włosy babci-trauma transgeneracyjna. „Psychiatria i Psychologia Kliniczna” 2014, nr 4, s. 89-94. 
Zuzanka ma choćby na chwilę zapełnić wyrwę w zagmatwanej autonarracji prowadzonej przez mamulkę - autonarracji krążącej wokół jednego zdjęcia, na którym znajdują się cztery dziewczynki. Babka umiejscawia wnuczkę na swoim miejscu, na co wskazują kolejne powtórzenia: „Ingeborga. Renate. Nina. Cztery dziołchy na zdjęciuchu. Ta mała, ta z wydrapaną gęba, to ja" (Kwo, s. 54). I dalej: „Cztery dziewczynki. Z tych dzieweczek tylko ja przeżyłam. A od tego zgniła się zrobiłam" (Kwo, s. 65).

Mamulka zostaje wydrapana ze zdjęcia wiszącego w straszliwej powojennej izbie pamięci i tym samym, niezdolna do potwierdzenia swojej tożsamości poprzez oparcie w wizerunku sprzed lat, staje się czymś w rodzaju własnego widma. Jej śląska tożsamość jest zreszta, wraz z nastaniem Polski Ludowej, właściwie nielegalna - mamulka zostaje przymusowo spolonizowana, przez co traci nawet własne imię. Była to powszechna przemocowa strategia władzy, której urzędnicy argumentowali, że chodzi jedynie o przywrócenie właściwych polskich imion, zniekształconych przez niemieckich intruzów rabujących wiecznie polskie, piastowskie ziemie. Śląska „Trybuna Robotnicza” opublikowała w 1946 roku tekst zatytułowany Czytelnicy piszą: "Precz z imionami szwabskimi!"25.

Mamulka jest ofiarą Tragedii Górnośląskiej - splotu zdarzeń, które sprawiają, że doświadczenia Ślązaków i Ślązaczek odbiegają od tych, które ujmuje się w standardowych polskojęzycznych narracjach dotyczących II wojny światowej ${ }^{26}$. W przypadku bohaterki Krótkiej wymiany ognia jest to przede wszystkim opowieść o wiecznym lęku i zagrożeniu, historia przemocy, często seksualnej: „Brali mnie tak, jak się bierze wiadro do dojenia krowy, we dwie łapy, między uda, szybko zanurza się w nim twarz [...] jeden po drugim, pędem, dawaj, następny" (Kwo, s. 173).

Potworne zdarzenia są przywoływane przez mamulkę, gdy ta mówi sama do siebie - nie stają się jawną częścią przechodzącego z matki na córkę przekazu, który mógłby zostać przez Romę wysłuchany, a następnie w jakimś stopniu przyswojony. Roma nie

25 [b.a.]: Czytelnicy pisza: „Precz z imionami szwabskimi!”. „Trybuna Robotnicza" 1946, nr 237, s. 5. Cyt. za: N. KLimaschKa: W obronie własnej tożsamości. Przymusowe zmiany nazwisk w powojennym Raciborzu. https://wachtyrz.eu/w-obroniewlasnej-tozsamosci-przymusowe-zmiany-nazwisk-w-powojennym-raciborzu/ [dostęp: 1.05.2020].

${ }^{26}$ Zob. E. Michna: Pomiędzy odzyskiwaniem pamięci a odpominaniem. II Wojna Światowa $i$ Tragedia Górnoślaska w narracjach dążacych do emancypacji liderów ślaskich. „Prace Etnograficzne” 2015, t. 43, nr 1, s. 1-12 oraz J. Најduк-Niјaкоwsкa: Rodzinna postpamięć Śląaków. „Politeja” 2017, nr 2, s. 159-171. 
może jednak zerwać traumatycznych więzów. Nękana przez braki i niedomówienia, musi sama ułożyć z odprysków mowy treść doświadczenia matki. Stąd powracający wątek nieznanego ojca Romy i jej zmarłej przedwcześnie siostry, której historia może być jednak w całości zmyślona ${ }^{27}$.

Ta postpamięciowa rekonstrukcja wiąże się również silnie z prześladującym bohaterkę powieści Rudzkiej widmem kilkuletniego chłopczyka. „Malutki topielec” pojawia się w snach Romy, choć ta nigdy go wcześniej nie spotkała. Jak się okazuje dopiero w końcowej sekwencji tekstu, należy on do pamięciowego porządku najboleśniejszych wspomnień matki Romy, która jako jedyna z kobiet z jej rodziny nie zdecydowała się popełnić samobójstwa w obliczu wejścia Armii Czerwonej na Górny Śląsk. Była ona świadkiem utopienia również tego chłopca, „niczyj synka, sobie tylko synka” (Kwo, s. 188).

Widmo to domaga się wyciągnięcia spod wody, uratowania, niczym w wierszu Paula Celana W Egipcie ${ }^{28}$. Roma nie jest w stanie tego uczynić: chłopiec ten nie może zostać godnie pochowany w pamięci, a na jego nagrobku nie może zaistnieć nieznane imię - wydrapane, odebrane, niemożliwe do ocalenia.

Widzę go wyraźnie. Przez całe życie chcę go zgubić z oczu. Chcę go wyprowadzić z pamięci. Chcę go wyciągnąć z przerębli, siłą złapać, wyprowadzić z tej zamarzniętej rzeki. Ubrać go. Ogrzać. Nakarmić. Przytulić. Nie umiem. Historia tej śmierci wypchnęła mnie na sam środek zamarzniętej rzeki, nie mogę się wydostać inaczej, jak tylko chwytając się słów.

Kwo, s. 186

Istnieją zaś, jak pamiętamy, tylko cudze, przechwycone słowa, które można wypowiadać w geście prozopopei. Roma musi je przejać, by zmagać się w swojej opowieści z tym, że jest nie tylko, by skorzystać z formuł Agnieszki Daukszy, „nosicielką pamięci”, ale również „nosicielką śmierci” ${ }^{29}$ (Kwo, s. 186), także tej nadchodzącej jako fantom. W ostatnim rozdziale powieści Roma usiłuje nieść w sobie również własną śmierć, pojawiając się w rodzinnym domu jako coś w rodzaju wizytującego trupa. Jak się okazuje, przed samobójstwem miała ogolone włosy (,ZZ wojny mamulka wyszła jak

27 Zob. Kwo, s. 57, 82-83, 154-156.

${ }^{28}$ P. Celan: W Egipcie. W: Idem: Psalm i inne wiersze. Przeł. R. Krynicki. Kraków 2013, s. 43.

29 Zob. A. Dauksza: Nosiciel pamięci. Ekonomia afektu Leo Lipskiego. W: EAdEM: Afektywny modernizm. Nowoczesna literatura polska w interpretacji relacyjnej. Warszawa 2017, s. 117-158. 
z choroby - łysa"; Kwo, s. 83 - tak przecież karano Polki za utrzymywanie relacji romantycznych i seksualnych z Niemcami) - być może również przyczyną jej śmierci było utonięcie. W ten sposób dopełnia się straszliwa rodzinna historia, naznaczona przez wielość traum o zatartych sygnaturach podmiotowych i czasoprzestrzennych.

Etyczne wyzwanie, które stawia przed sobą nie tylko bohaterka Krótkiej wymiany ognia, ale również, jak sądzę, sama Rudzka, jest więc bardzo poważne. Roma mówi: „Moja jedyna wiara to rozpisywanie. Nadpisywanie życia dzieci nad życie rodziców. Przepisywanie życia umarłych na życie żywych" (Kwo, s. 123).

Dzięki urywkom przekazów, dziwnym słowom i dopuszczeniu głosów innych możliwe staje się, by przemówiło to, co dotychczas nigdy nie mogło się ujawnić: $\mathrm{z}$ trudem, w jedyny sobie znany sposób, zaświadczając o straszliwych zdarzeniach infekujących życie. W próbach rozpisania krótkich wymian ognia język na chwilę może zbliżyć się do bolesnego miejsca - do tego, co nęka i uparcie nie daje spokoju.

\section{Bibliografia}

[b.a.]: Czytelnicy pisza: „Precz z imionami szwabskimi!”. „Trybuna Robotnicza” 1946, nr 237, s. 5 .

Aвraham N.: Notes on Phantom: A Complement to Freud's Metapsychology. Transl. N. RAND. "Critical Inquiry” 1987, vol. 13, no 2, s. 287-292.

ARtwińska A.: „Odrodziły się traumy z czasów Zagłady”. Marzec 1968 jako narracja postkatastroficzna. „Poznańskie Studia Polonistyczne” 2015, nr 25, s. 187-208.

BeŁza M.: Zimne ognie. „Mały Format” 2018, nr 4. http://malyformat.com/2018/04/ zimne-ognie/ [dostęp: 1.05.2020].

Celan P.: W Egipcie. W: Idem: Psalm i inne wiersze. Przeł. R. Krynicki. Kraków 2013, s. 43.

Dauksza A.: Nosiciel pamięci. Ekonomia afektu Leo Lipskiego. W: EAdem: Afektywny modernizm. Nowoczesna literatura polska $w$ interpretacji relacyjnej. Warszawa 2017, s. 117-158.

Dunin K.: Zajrzeć do studni. https://krytykapolityczna.pl/kultura/czytaj-dalej/kin ga-dunin-czyta/zyta0rudzka-recenzja-zajrzec-do-studni/ [dostęp: 1.05.2020].

Најduк-Nijakowska J.: Rodzinna postpamięć Ślazaków. „Politeja” 2017, nr 2, s. $159-171$.

Hirsch M.: Żałoba i postpamięć. Przeł. K. Bojarska. W: Teoria wiedzy o przeszłości na tle wspótczesnej humanistyki. Red. E. DomańsKa. Poznań 2010, s. 247-280.

KLicka B.: Zdrój. Warszawa 2019.

Klimaschкa N.: W obronie własnej tożsamości. Przymusowe zmiany nazwisk w powojennym Raciborzu. https://wachtyrz.eu/w-obronie-wlasnej-tozsamosci-przy musowe-zmiany-nazwisk-w-powojennym-raciborzu/ [dostęp: 1.05.2020]. 
KLimowicz B.: Straszna pani bez godności, czyli przemilczenia w recepcji „Krótkiej wymiany ognia” Zyty Rudzkiej. „Kultura Liberalna” 2018, nr 22, [b.n.s.]. https:// kulturaliberalna.pl/2018/05/29/beata-klimowicz-recenzja-zyta-rudzka-krot ka-wymiana-ognia/ [dostęp: 1.05.2020].

Leociak J.: Doświadczenie graniczne. Studia o dwudziestowiecznej formie reprezentacji. Warszawa 2009.

Łucka I., Nowak P.: Włosy babci - trauma transgeneracyjna. „Psychiatria i Psychologia Kliniczna" 2014, nr 4, s. 89-94.

Malabou C.: Ontologia przypadłości. Esej o plastyczności destrukcyjnej. Przeł. P. SKalski. Warszawa 2017.

Michna E.: Pomiędzy odzyskiwaniem pamięci a odpominaniem. II Wojna Światowa $i$ Tragedia Górnoślaska w narracjach dążacych do emancypacji liderów śląskich. „Prace Etnograficzne" 2015, t. 43, nr 1, s. 1-12.

Nowacki D.: „Krótka wymiana ognia” Zyty Rudzkiej: świetny powieściowy powrót po kilkunastu latach przerwy. „Gazeta Wyborcza”, 9.04.2018.

Окrajni M.: Zakotwiczenie (w) przeszłości (Zyta Rudzka: „Krótka wymiana ognia”). „artPapier” 2018, nr 13. http://artpapier.com/index.php?page=artykul\&wyda nie=351\&artykul=6865\&kat=1 [dostęp: 1.05 .2020$]$.

Rudzka Z.: Fastryga. „Notatnik Teatralny” 2009, nr 57-58, s. 250-282.

Rudzka Z.: Krótka wymiana ognia. [Utwór dramaturgiczny]. „Dialog” 2014, nr 4, s. $21-41$.

RudzKa Z.: Krótka wymiana ognia. Warszawa 2018.

Rudzka Z:: Mykwa. Izabelin 1999.

Rudzka Z.: Zimny bufet. http://www.gnd.art.pl/wp-content/uploads/2014/05/ zimny_bufet_zyta_rudzka.pdf [dostęp: 1.05.2020].

SAdzik P.: Rozpylenia. Marańskie montaże Leopolda Buczkowskiego. „Teksty Drugie” 2019, nr 4, s. 89-112.

Sowińska A.: Czas na inne piosenki. Rozmowa z Zyta Rudzka. „Dwutygodnik” 2018, nr 3, [b.n.s]. https://www.dwutygodnik.com/artykul/7740-czas-na-inne-piosenki.html [dostęp: 1.05.2020].

Ubertowska A.: Praktykowanie postpamięci. Marianne Hirsch i fotograficzne widma z Czernowitz. „Teksty Drugie” 2013, nr 4, s. 269-289.

WróBel O.: Odważniej. „Dwutygodnik” 2018, nr 3, [b.n.s]. https://www.dwutygo dnik.com/artykul/7696-odwazniej.html [dostęp: 1.05.2020].

Antoni Zając - student Kolegium Międzyobszarowych Interdyscyplinarnych Studiów Humanistycznych na Uniwersytecie Warszawskim. Autor tekstów naukowych i krytycznych o literaturze. Zajmuje się związkami między teologią (w szczególności żydowską), filozofią i literaturą oraz wątkami postsekularnymi w literaturze XX i XXI wieku. W ramach programu Diamentowy Grant realizuje projekt badawczy poświęcony twórczości Leo Lipskiego.

e-mail: antoni.m.zajac@gmail.com 